\title{
THE EFFECT OF ATROPINE UPON GASTRIC SECRETION AFTER HISTAMINE STIMULATION
}

By W. SCOTT POLLAND

(From the Department of Medicine, Stanford University Medical School, San Francisco)

(Received for publication April 2, 1930)

It is generally assumed by physicians that atropine decreases gastric secretion, and although many studies have been made on animals and man, few exact details as to its action in man are known. Histamine, although studied extensively by pharmacologists and physiologists, since the work of Dale and Richards (1), has only recently interested the clinician. This has come about as a natural development of the work of Popielski $(2,3)$, who found that histamine was a powerful stimulant of gastric secretion in dogs, and later of Carnot, Koskowski and Libert (4), who described its action on the stomach in man. Bloomfield and Polland (5) have recently described a method by which it has been found to be of diagnostic value in studies on gastric secretion. It seemed advisable to study the effect of atropine on the gastric secretion caused by histamine in man. It was thought that such studies might enable one to estimate more accurately the value of histamine as a stimulating agent; and at the same time throw some light on the more fundamental problems of gastric secretion.

\section{IITERATURE}

Keeton, Luckhardt and Koch (6) using dogs with Pavlov pouches or gastric fistulae showed that there was an antagonism between histamine and atropine. In their experiments, even after temporary inhibition by atropine, histamine always produced a reappearance of secretion. They noted that if atropine was given after histamine, there was first a fall in the quantity of secretion and pepsin, followed later by a reduction in acid. They suggested that this indicated a different secretory mechanism for pepsin and acid. No similar studies have been made on man. 
As regards the effect of atropine on gastric secretion, the literature abounds with conflicting and contradictory reports. A review of the bibliography is beyond the scope of this paper. Altshuler (7) has recently surveyed the experimental work, and attempted to reconcile contradictory observations on the basis that the action of drugs depends upon what phase of activity the cells are in when the stimulus reaches them. He believes that the same drug acting on the same cell might at one time result in stimulation, and at another in inhibition.

\section{METHODS}

Exactly the same procedure was used as has been previously described (5), except that after the volume of secretion and titrable acidity had practically returned to normal, a second injection of histamine ( $0.1 \mathrm{mgm}$. per 10 kilograms body weight) and atropine $(0.2 \mathrm{mgm}$. per 10 kilograms body weight) was administered subcutaneously. The response to histamine alone was taken as a control for the subsequent effect of histamine and atropine. Previous studies in this laboratory (8) have shown that repeated injections of histamine that follow after the effect of a former injection has worn off, produce practically the same titratable acidity and volume response. The dose of atropine used was sufficient to produce mild toxic symptomsdryness of mouth and blurring of vision.

The following determinations were made on the various ten-minute specimens: $(a)$ volume, $(b)$ titratable acidity, and $(c)$ pepsin. Titratable acidity was determined with di-methyl and phenolphthalein in the usual way, and pepsin according to the method of Polland and Bloomfield (9).

\section{MATERIAL}

Seven patients were studied Four of these presented no evidence of organic disease of the stomach; three were cases of duodenal ulcer. Volume and titratable acidity were measured in all, and pepsin was determined in 4 cases. Table 1 shows a complete protocol to illustrate the procedure.

\section{RESULTS}

Case 1. R., a man, age 21 with evidence of mental retardation, had never had any symptoms of gastric disease. The results of the examination are shown in 
chart 1. The control period showed a secretion of normal volumes and titratable acidity. At the end of the period both had practically returned to the fasting level. After the administration of histamine and atropine, there was a brisk temporary rise in the volume per ten-minute period followed by a fall below that of the fasting level. On the other hand, the titratable acidity' mounted to a level much higher than with histamine alone, and remained relatively high even when the volume of secretion was low. In spite of the rise in titratable acidity, the total output of acid fell with the volumes.

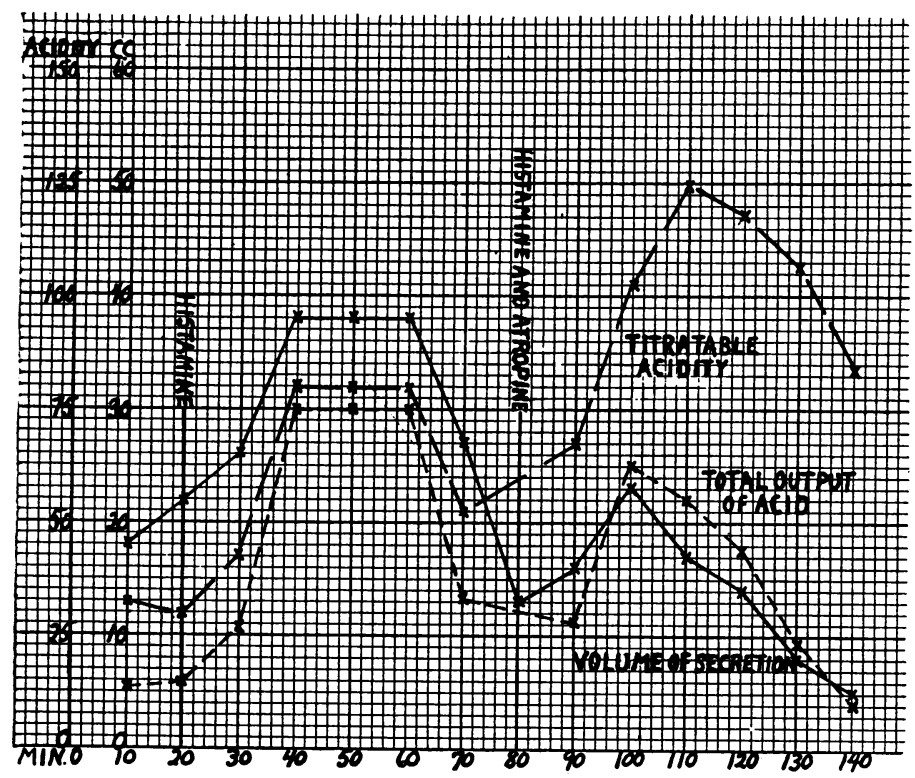

Chart 1. Curves of Volume of Secretion, Titratable Acidity, and Total Output of Acid from Case 1 At Ten-minute Intervals After Histamine, and After Histamine and Atropine

Case 2. G. B., a man, age 42 , had symptoms of mild indigestion for ten years. Physical examination was negative. Stools were negative for occult blood. Xrays showed no evidence of disease of the stomach. His symptoms partially subsided after a short stay in the hospital. The control period showed secretion

${ }^{1}$ Throughout this paper, titratable acidity refers to the number of cubic centimeters of $\mathrm{N} / 10 \mathrm{NaOH}$ necessary to neutralize $100 \mathrm{cc}$. of gastric juice with phenolphthalein as an indicator. The total output of acid represents the total amount of acid secreted per ten-minute period expressed as $\mathrm{x} / 10 \mathrm{HCl}$. 


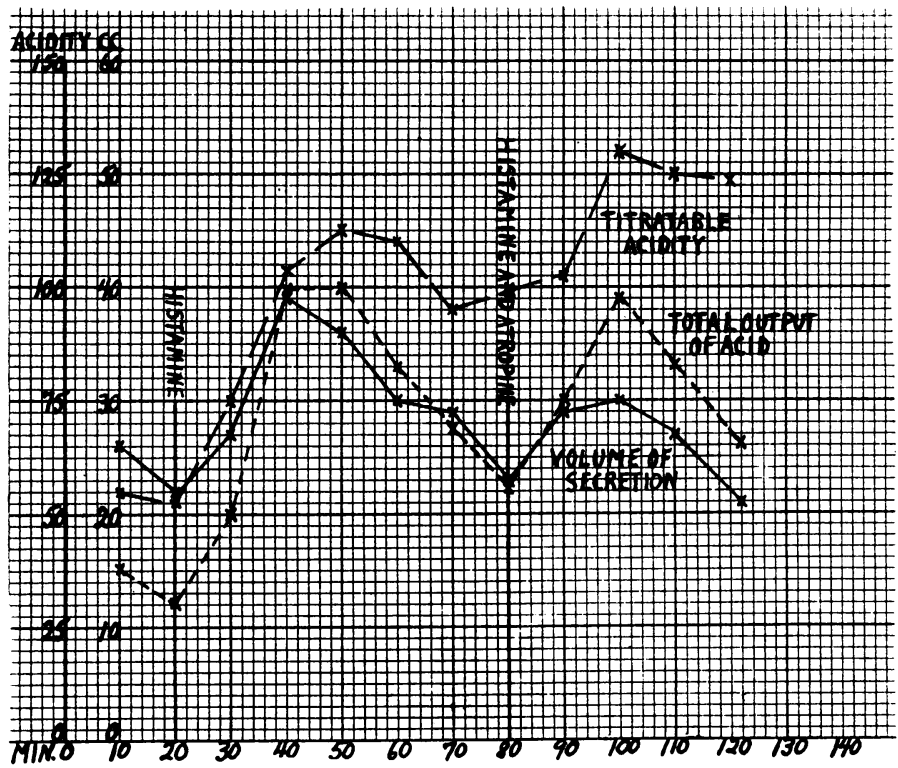

Chart 2. Curves of Volume of Secretion, Titratable Acidity, and Total Output of Acid from Case 2 at Ten-minute Intervals After Histamine, and After Histamine and Atropine

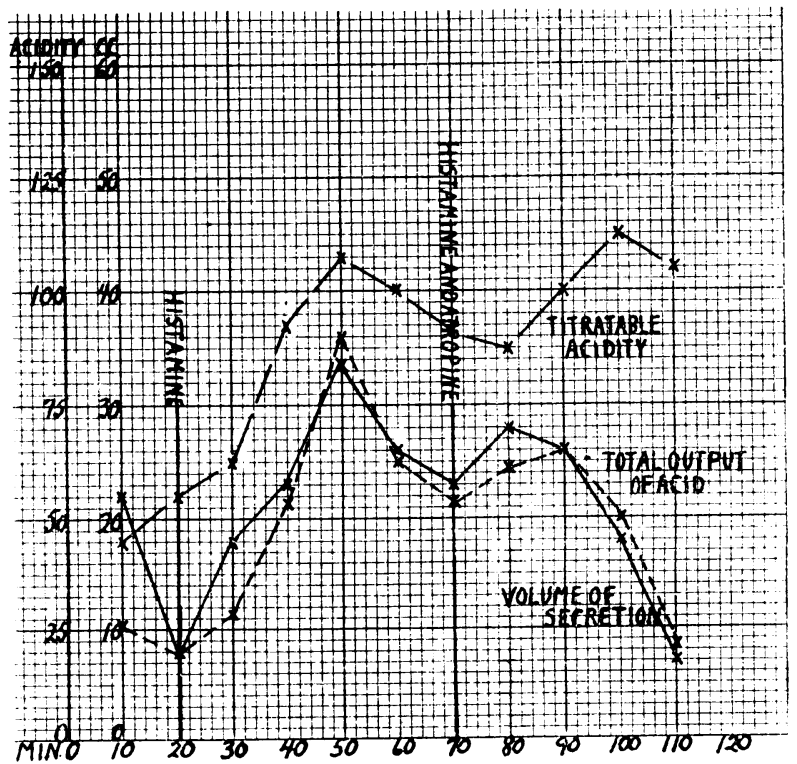

Chart 3. Curves of Volume of Secretion, Titratable Acidity, and Total Output of Acid from Case 3 at Ten-minute Intervals After Histamine, and After Histamine and Atropine 
of normal amounts of juice of normal titratable acidity (chart 2). After histamine and atropine, there was a transient rise of the volume per ten-minute period, followed by a fall. Simultaneously, there was a marked rise in the titratable acidity, but the total output of acid was diminished.

Case 3. A. M., a woman, age 48 , had symptoms of indigestion relieved by food or soda for seven years. Physical examination and laboratory studies were essentially negative. Gastro-intestinal x-rays showed a constant constriction of

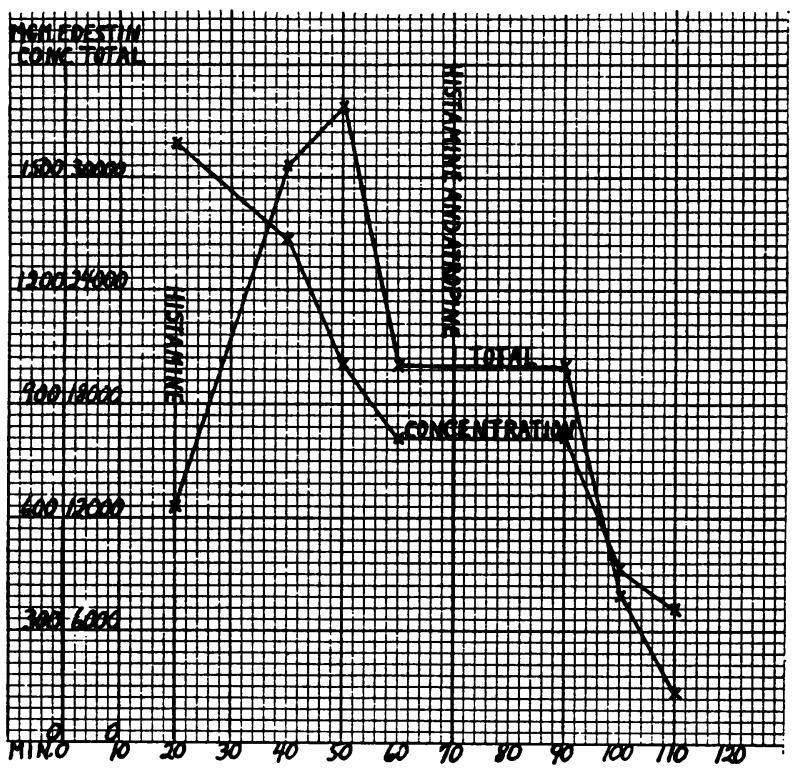

Chart 4. Curves of Concentration and Total Output of Pepsin from Case 3 at Ten-minute Intervals After Histamine, and After Histamine and ATROPINE

the duodenum, and the $\mathrm{x}$-ray diagnosis was duodenal ulcer. The control examination showed the volumes and titratable acidity were within normal limits (chart 3). After histamine and atropine the titratable acidity rose while the volumes fell. Even after the volume had fallen to $7 \mathrm{cc}$. per ten-minute period, the titratable acidity remained high $-105 \mathrm{cc} . \mathrm{N} / 10 \mathrm{HCl}$ per $100 \mathrm{cc}$. of juice. The total outpuit of acid was, as usual, decreased. Chart 4 shows the effect of histamine and atropine upon pepsin. (Pepsin is expressed in terms of the number of milligrams of edestin digested by one cubic centimeter of gastric juice in 30 minutes.) The control period shows, as has been previously noted (10), a fall in concentration but a 
transient rise in total output of pepsin after histamine. After histamine and atropine, there is a marked fall in both the concentration and total output of pepsin for each ten-minute period.

Case 4. J. G., a boy, age 17, entered the hospital for minor complaints and showed no evidence of organic disease. The control volumes and titratable

TABLE 1

Complete protocol of a typical experiment (Case 4)

\begin{tabular}{|c|c|c|c|c|c|c|c|c|}
\hline \multirow[b]{2}{*}{$\begin{array}{l}\text { Number } \\
\text { of } \\
\text { specimen }\end{array}$} & \multirow[b]{2}{*}{ Time } & \multirow[b]{2}{*}{ Amount } & \multirow[b]{2}{*}{ Character } & \multicolumn{3}{|c|}{ Acid titratable } & \multicolumn{2}{|c|}{ Pepsin } \\
\hline & & & & Free & Total & $\begin{array}{l}\text { Output } \\
\text { per } \\
\text { period }\end{array}$ & $\begin{array}{l}\text { Edestin } \\
\text { digested } \\
\text { by } 1 \mathrm{cc} \text {. } \\
\text { of juice }\end{array}$ & $\begin{array}{c}\text { Total } \\
\text { edestin } \\
\text { digested } \\
\text { per } 10 \\
\text { minute } \\
\text { period }\end{array}$ \\
\hline & p.m. & $c c$. & & $\begin{array}{l}\text { cc. } N / 10 \\
\text { per } 100 \text { cc. }\end{array}$ & $\begin{array}{l}\text { cc. } N / 10 \\
\text { per } 100 \text { cc. }\end{array}$ & cc. $N / 10$ & $m g m$. & $m g m$ \\
\hline 1 & $1: 50$ & 60 & $\begin{array}{l}\text { Fasting contents. } \\
\text { Water clear, } \\
\text { small amounts } \\
\text { mucus }\end{array}$ & 22 & 33 & 19.8 & & \\
\hline 2 & $2: 00$ & 23 & $\begin{array}{l}\text { Water clear, small } \\
\text { amount mucus }\end{array}$ & 46 & 56 & 12.88 & & \\
\hline
\end{tabular}

Histamine $0.6 \mathrm{mgm}$.

\begin{tabular}{l|l|l|l|r|r|r|r|r}
\hline 3 & $2: 10$ & 30 & Water clear & 81 & 88 & 26.4 & 1,910 & 57,300 \\
4 & $2: 20$ & 39 & Water clear & 94 & 102 & 39.78 & & \\
5 & $2: 30$ & 33 & Water clear & 108 & 118 & 38.94 & 899 & 29,700 \\
6 & $2: 40$ & 22 & Water clear & 98 & 112 & 24.64 & & \\
7 & $2: 50$ & 17 & Water clear & 62 & 83 & 14.11 & 667 & 11,340 \\
\hline
\end{tabular}

Histamine $0.6 \mathrm{mgm}$., atropine $1.2 \mathrm{mgm}$.

\begin{tabular}{r|r|r|l|r|r|r|r|r}
\hline 8 & $3: 00$ & 16 & Water clear & 84 & 100 & 16.0 & 1,150 & 18,410 \\
9 & $3: 10$ & 20 & Water clear & 116 & 128 & 25.6 & 684 & 13,680 \\
10 & $3: 20$ & 17 & Water clear & 128 & 137 & 23.29 & 522 & 8,901 \\
11 & $3: 30$ & 14 & Water clear & 138 & 146 & 20.44 & 424 & 5,980 \\
\hline
\end{tabular}

acidity were normal (table 1 and chart 5). After histamine and atropine, the volumes and total output of acid fell, while the titratable acidity rose as in cases 1 , 2 and 3 . Chart 6 shows that after histamine there is a fall in the concentration and total output of pepsin, followed, after histamine and atropine, by a slight rise, then a further fall of both. 


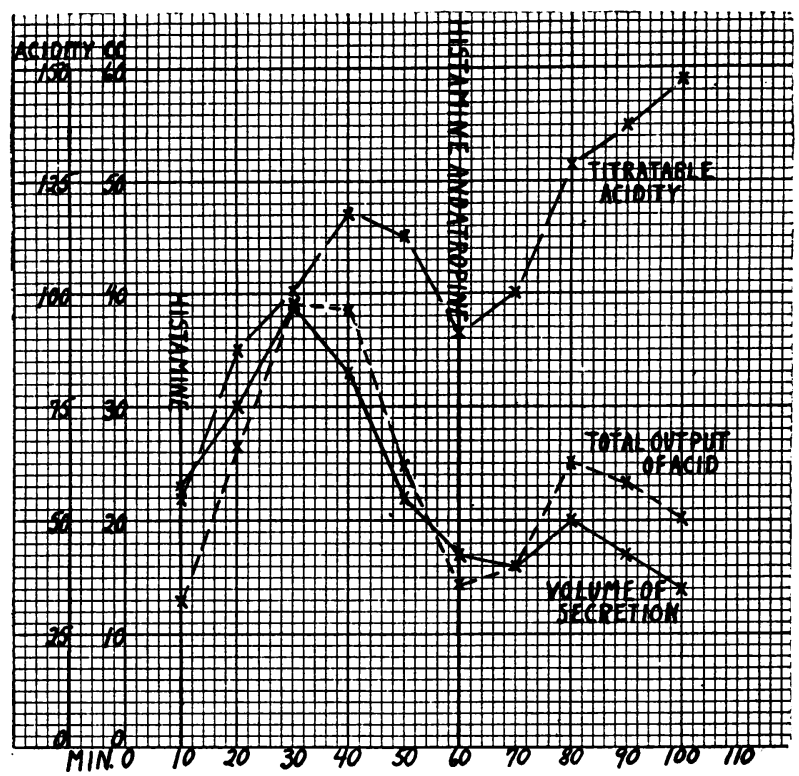

Chart 5. Curves of Volume of Secretion, Titratable Acidity, and Total Output of Acid from Case 4 at Ten-minute Intervals After Histamine, and After Histamine and Atropine

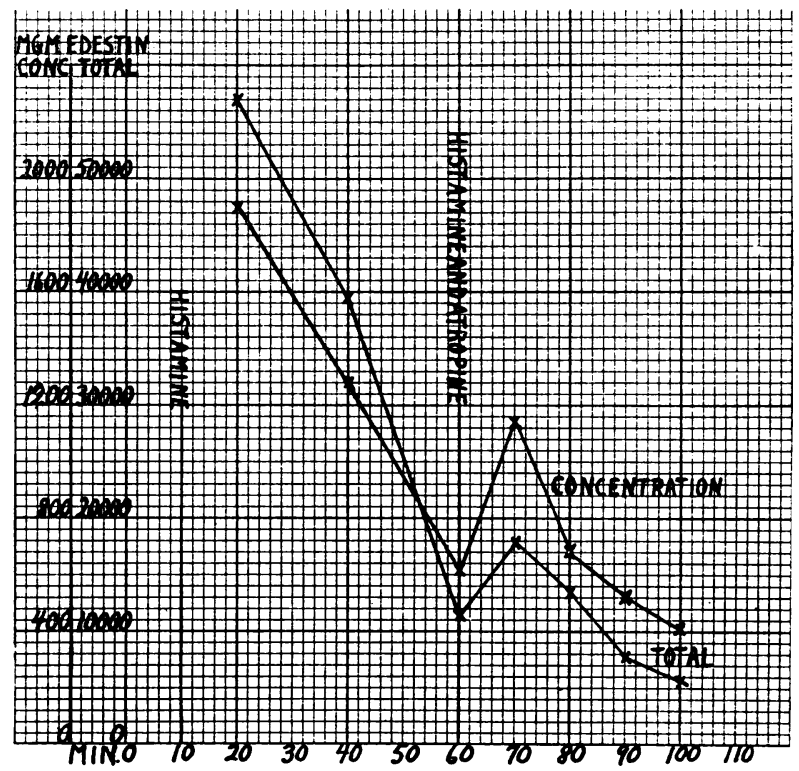

Chart 6. Curves of Concentration, and Total Output of Pepsin from Case 4 at Ten-minute Intervals After Histamine, and After Histamine and ATROPINE 


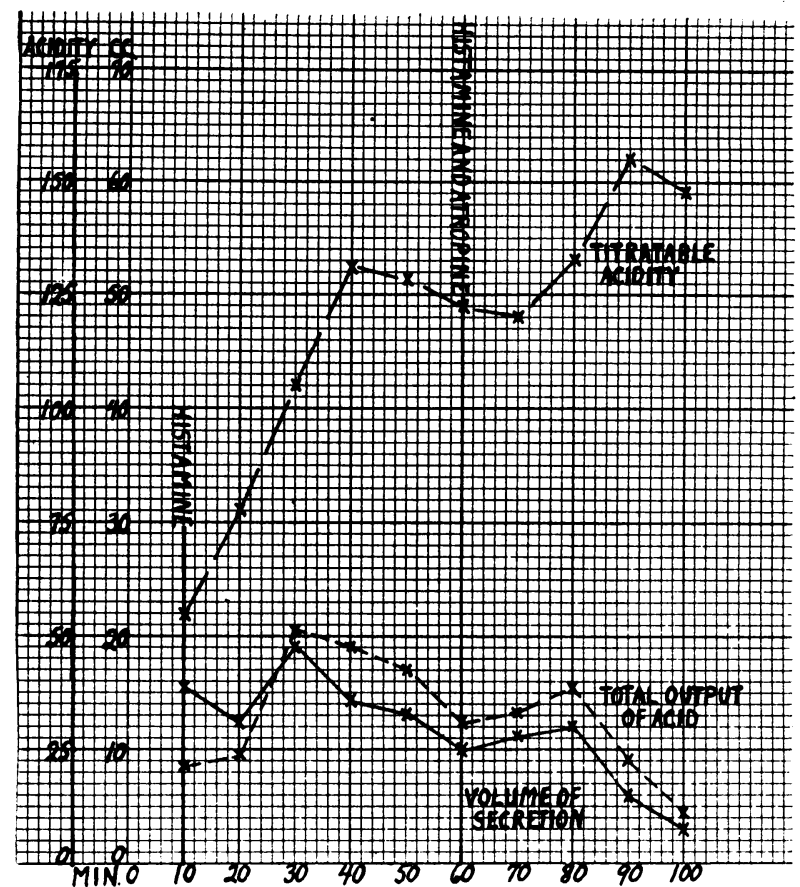

Chart 7. Curves of Volume of Secretion, Titratable Acidity, and Total Output of Acid from Case 5 at Ten-minute Intervals After Histamine, 4nd After Histamine and Atropine

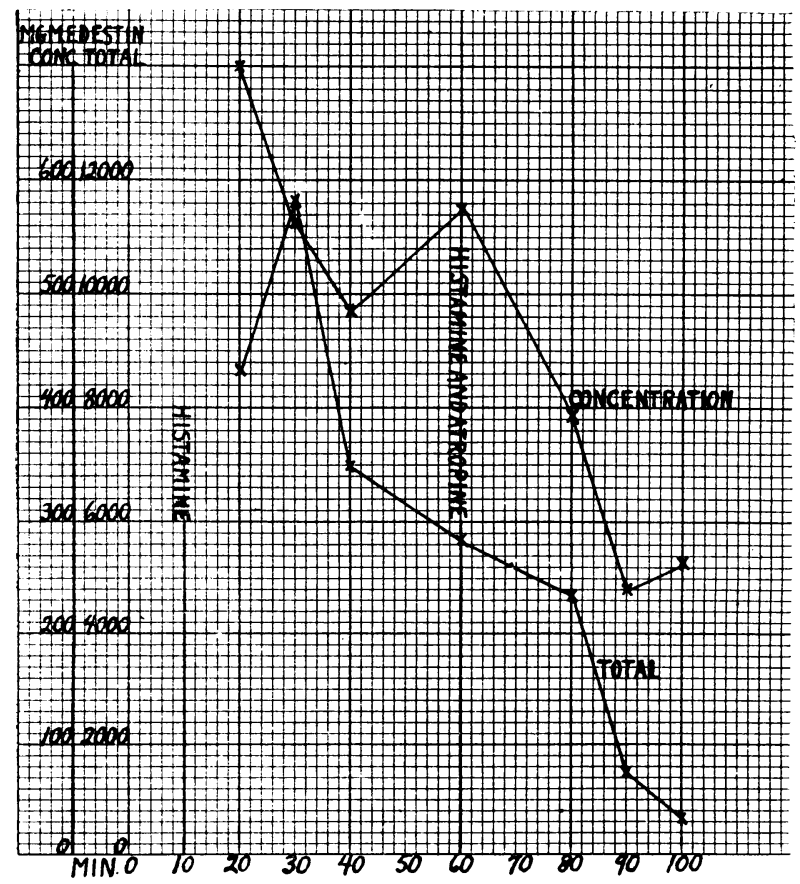

Chart 8. Curves of Concentration, and Total Output of Pepsin from Case 5 at Ten-minute Intervals After Histamine a.jd After Histamine and ATropine 
Case 5. L. L., a woman, age 30, entered the hospital because of nervousness. No evidences of organic disease of any kind were found. The volume response to histamine was low, but the titratable acidity was normal (chart 7). After histamine and atropine, the volumes fell to the very low level of $3 \mathrm{cc}$. per ten-minute period, while the titratable acidity reached the remarkable level of 155 . The total output of acid fell with the volumes. Both the concentration and total output of pepsin fell markedly after histamine and atropine (chart 8).

TABLE 2

Data from case 6

\begin{tabular}{|c|c|c|c|c|c|c|c|}
\hline 运 & & & . & $\begin{array}{r}\text { Titra } \\
\text { aci }\end{array}$ & $\begin{array}{l}\text { table } \\
\text { lity }\end{array}$ & & psin \\
\hline 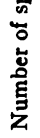 & $\stackrel{g}{\rightleftarrows}$ & 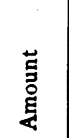 & Character & Free & Total & $\begin{array}{l}\text { Edestin } \\
\text { digested } \\
\text { by } 1 \text { cc. } \\
\text { of juice }\end{array}$ & $\begin{array}{c}\text { Total } \\
\text { edestin } \\
\text { digested } \\
\text { per 10 } \\
\text { minute } \\
\text { period }\end{array}$ \\
\hline & p.m. & $c c$. & & $\begin{array}{c}c c . \\
N / 10 \\
\text { per } \\
100 c c .\end{array}$ & $\begin{array}{c}c c . \\
N / 10 \\
\text { per } \\
100 \text { cc. }\end{array}$ & $m g m$. & $m g m$. \\
\hline 1 & $2: 25$ & 30 & $\begin{array}{l}\text { Fasting contents. Thin, colorless, some } \\
\text { mucus }\end{array}$ & 40 & 58 & & \\
\hline 2 & $2: 35$ & 38.5 & Thin, clear & 84 & 94 & 1,485 & 57,190 \\
\hline 3 & $2: 45$ & 36 & Thin, clear & 94 & 102 & & \\
\hline 4 & $2: 55$ & 28 & Thin, clear & 102 & 112 & 1,770 & 49,500 \\
\hline 5 & $3: 05$ & 25 & Thin, faint brownish tinge (blood) & 106 & 116 & & \\
\hline 6 & $3: 15$ & 31 & Thin, faint brownish tinge (blood) & 104 & 114 & 1,615 & 50,400 \\
\hline 7 & $3: 25$ & 36 & Thin, faint brownish tinge (blood) & 80 & 90 & & \\
\hline
\end{tabular}

Histamine $0.7 \mathrm{mgm}$., atropine $1.4 \mathrm{mgm}$.

\begin{tabular}{r|l|l|l|l|l|r|r}
\hline 8 & $3: 35$ & 31.5 & Thin, faint brownish tinge (blood) & 112 & 122 & 1,770 & 54,900 \\
9 & $3: 45$ & 33 & Thin, faint brownish tinge (blood) & 124 & 132 & & \\
10 & $3: 55$ & 37 & Thin, faint brownish tinge (blood) & 126 & 134 & 788 & 27,160 \\
11 & $4: 05$ & 33.5 & Thin, faint brownish tinge (blood) & 124 & 134 & & \\
\hline
\end{tabular}

Case 6. J. M., a man, age 54, entered the hospital for treatment of a duodenal ulcer of many years duration. His fasting secretion was very high-194.5 cc. of juice per hour, having an average titratable acidity of 105 (table 2 and chart 9). After histamine and atropine, the rate of secretion remained about the same, but the titratable acidity rose from 116 to 134 . The concentration of pepsin fell from 1770 milligrams to 788 milligrams edestin digested by $1 \mathrm{cc}$. of juice (chart 10), and the total output of pepsin fell from $57,190 \mathrm{mgm}$. to $29,160 \mathrm{mgm}$. edestin digested per ten-minute period. 


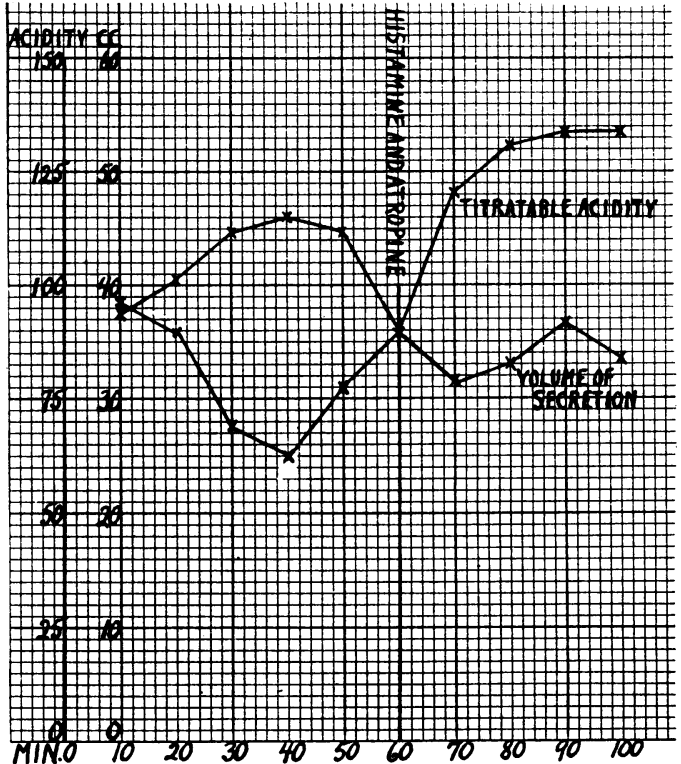

Chart 9. Curves of Volume of Secretion, and Titratable Acidity from Case 6 Before and After Histamine and Atropine

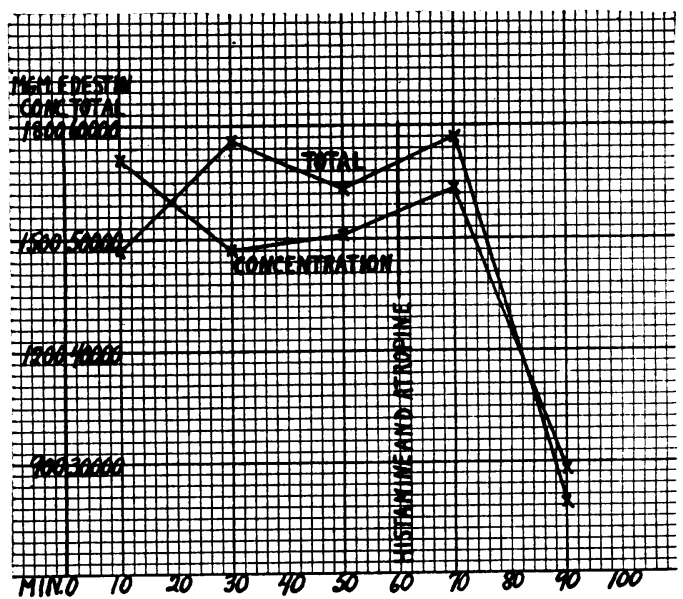

Chart 10. Curves of Concentration and Total Output of Pepsin from Case 6 at Ten-minute Intervals Before and After Histamine and Atropine 
Case 7. F. A., a man, age 30 , had symptoms of indigestion for 20 months. The $\mathrm{x}$-ray diagnosis was duodenal ulcer and his symptoms promptly subsided on a modified Sippy regime. After histamine, the volumes and titratable acidity were high (chart 11). After histamine and atropine, the usual response occurred; the titratable acidity rose while the volumes fell. After the volume had reached a

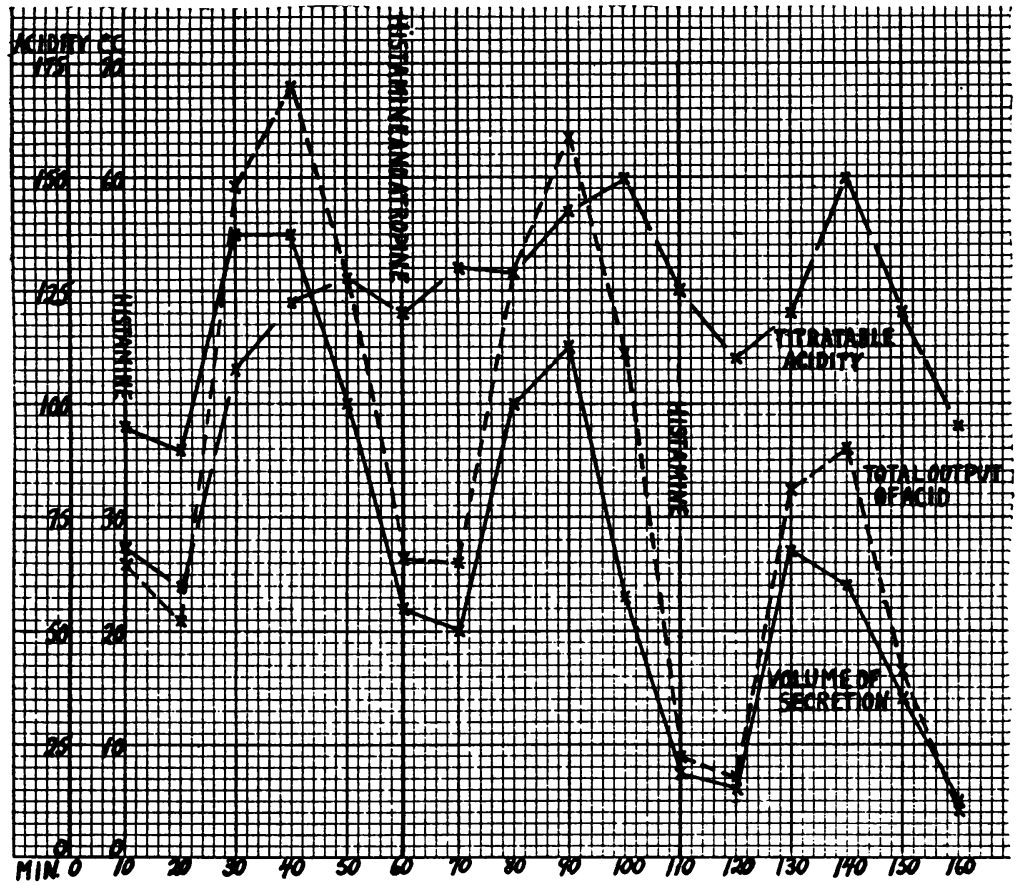

Chart 11. Curves of Volume of Secretion, Titratable Acidity, and Total Output of Acid from Case 7, at Ten-minute Intervals After Histamine, After Histamine and Atropine and After a Second Injection of Histamine

secretory rate of $7 \mathrm{cc}$. per ten-minute period, another dose of histamine was administered. Although the volumes reached $27 \mathrm{cc}$. per ten-minute period, this was less than half the first response to histamine. However, the titratable acidity rose to a maximum of 150 , as compared to the previous response to histamine of 128. 


\section{DISCUSSION}

A survey of the foregoing charts shows several striking facts:

1. Volume of secretion. It is immediately apparent that the volume of secretion is smaller after histamine and atropine, than with histamine alone. In the control period, the output reached its maximum in 20 to 30 minutes and then began to fall, reaching the pre-histamine level in about 50 to 60 minutes. On the other hand, after histamine and atropine, there was usually a slight rise in the volume, followed by a marked fall. Even a second dose of histamine (case 7) failed to produce the normal volume response, while the effect of atropine was still present. These facts are shown quantitatively in table 3.

TABLE 3

Comparison of volume of secretion, average titratable acidity, and total acid output in the first 40 minutes after histamine, and after histamine and atropine

\begin{tabular}{|c|c|c|c|c|c|c|}
\hline \multirow{2}{*}{ Case } & \multicolumn{2}{|c|}{ Volume secreted } & \multicolumn{2}{|c|}{ Titratable acidity } & \multicolumn{2}{|c|}{ Total output of acid } \\
\hline & Histamine & $\begin{array}{c}\text { Histamine } \\
\text { and atropine }\end{array}$ & Histamine & $\begin{array}{l}\text { Histamine } \\
\text { and atropine }\end{array}$ & Histamine & $\begin{array}{l}\text { Histamine } \\
\text { and atropine }\end{array}$ \\
\hline & $c \iota$. & $c c$. & $\begin{array}{l}\text { cc. N/10 per } \\
100 \text { cc. }\end{array}$ & $\begin{array}{l}\text { cc. N/10 per } \\
100 \text { cc. }\end{array}$ & cc. $N / 10$ & cc. $N / 10$ \\
\hline 1 & 140 & 71.5 & 61 & 93 & 88.5 & 67.08 \\
\hline 2 & 132 & 107 & 100 & 120.5 & 133.47 & 128.61 \\
\hline 3 & 101 & 79 & 90.5 & 101.3 & 95.02 & 78.15 \\
\hline 4 & 124 & 67 & 105 & 127.8 & 129.76 & 85.33 \\
\hline 5 & 59.5 & 33 & 111.3 & 139 & 66.93 & 44.17 \\
\hline 7 & 186 & 128 & 105 & 137.5 & 200.4 & 175.6 \\
\hline
\end{tabular}

2. Acidity. Keeton, Luckhardt and Koch pointed out that in dogs the volume of secretion after atropine diminished more rapidly than the titratable acidity. The present experiments show that in man the titratable acidity rises after histamine and atropine, often to extremely high levels. This is in striking contrast to the volume of secretion. In case 5 , for example, the titratable acidity reached 155 , while the volume fell to $3 \mathrm{cc}$., and in case 3 the titratable acidity was 105 , while the volume was $7 \mathrm{cc}$. This complete dissociation of the usual coordinated response to histamine suggests that water and acid are secreted by different mechanisms. If the curves for titratable acidity and volume of secretion are alone considered, it would appear 
that the increase in concentration of acid after histamine and atropine was due only to a decrease in volume of water secretion, and that there was no direct effect upon acid secretion. However, if the total output of acid is studied, it is clearly seen that atropine has also a definite inhibitory action on acid secretion. In table 3 is a summary of the actual quantitative relations.

It is believed that the present observations explain why most authorities have found a diminution in the titratable acidity after the administration of atropine. If bread, water, gruel, beef broth or alcohol are used to study gastric secretion, no true index of titratable acidity can be obtained because of the diluting effect of the meal itself. If the actual concentration of acid is higher, but the total output is lower for any given period of observation, the introduction of a diluting agent will give a false idea of the true concentration of the acid. Obviously, this error does not occur if pure gastric juice is studied, such as is obtained after histamine stimulation. However, it is also important to remember that the study of the concentration alone of a given substance is insufficient, and often misleading. Unless one considers the total output, or rate of secretion of a given substance, no true index of the functional state of the stomach can be obtained. This is strikingly shown in all the cases, if the titratable acidity was alone considered, and the total output disregarded In that case the conclusion would have to be that atropine always augmented acid secretion after histamine. Certainly this conclusion is false when one considers the total output of acid.

3. Pepsin. A survey of the pepsin curves shows that after histamine and atropine, the concentration is decreased. The effect on pepsin is more strikingly shown if the total output is considered. The latter seems to parallel the fall in volume of secretion. However, in case 6 the concentration and total output of pepsin fell before the volume of secretion was affected; in cases 4 and 5 the concentration and total output were falling while the volume of secretion was rising. Previous studies (11) have suggested that pepsin and water are not secreted by the same mechanism, and the present study is additional evidence in favor of such a theory. It is clear that the secretion of pepsin has no relation to the secretion of acid. 


\section{SUMMARY}

Curves are presented comparing the course of gastric secretion after histamine with that after histamine and atropine. The volume of secretion, titratable acidity, concentration of pepsin, total output of acid and total output of pepsin have been studied. Atropine dissociates the normal response to histamine, producing a marked decrease in the volume of secretion, and in the concentration and total output of pepsin. The titratable acidity rises as a result of the only slight inhibitory effect of atropine on the total output of acid.

The results suggest that water, acid and pepsin may have different mechanisms of secretion.

\section{BIBLIOGRAPHY}

1. Dale, H. H., and Richards, A. N., J. Physiol., 1918, lii, 110. The Vasodilator Action of Histamine and of Some Other Substances.

2. Popielski, L., Arch. f. d. ges. Physiol., 1920, clxxviii, 214. B-imidazolyläthylamin und die Organextrakte Erster Teil. B-imidazolyläthylamin als mächtiger Erreger der Magendrüsen.

3. Popielski, L., Arch. f. d. ges. Physiol., 1920, clxxviii, 237. B-imidazolyläthylamin und die Organextrakte: Zweiter Teil. Einfluss der Säuren auf die die Magensaftsekretion errengende Wirkung der Organextrakte.

4. Carnot, P., Koskowski, W., and Libert, E., Compt. rend. de la Soc. de Biol., 1922, lxxxvi, 575. L'Influence de l'Histamine sur la Sécrétion des Sucs Digestifs chez l'Homme.

5. Bloomfield, A. L., and Polland, W. S., J. Am. Med. Assoc., 1929, xcii, 1508. The Diagnostic Value of Studies of Gastric Secretion.

6. Keeton, R. W., Luckhardt, A. B., and Koch, F. C., Am. J. Physiol., 1920, li, 469. Gastrin Studies: II. The Response of Stomach Mucosa to Food and Gastrin Bodies As Influenced by Atropine.

7. Altshuler, A. M., Arch. Int. Med., 1928, xlii, 117. Gastric Secretion: Its alteration by the Use of Atropine, Epinephrine and Pilocarpine.

8. Sampson, J. P., Unpublished Observations.

9. Polland, W. S., and Bloomfield, A. L., J. Clin. Invest., 1929, vii, 45. A Quantitative Method for the Estimation of Pepsin.

10. Polland, W. S., and Bloomfield, A. L., J. Clin. Invest., 1929, vii, $57 . \quad$ Quantitative Measurements of Pepsin in Gastric Juice before and after Histamine Stimulation.

11. Polland, W. S., and Bloomfield, A. L., J. Clin. Invest., 1930, ix, 107. The Diagnostic Value of Determinations of Pepsin in Gastric Juice. 